\title{
Secular changes of height and body mass of children and youth in the Bydgoszcz region
}

\author{
Grzegorz Nowicki \\ Department of Physical Education, Bydgoszcz Academy (WSP), \\ Chodkiewicza 30, 85-064 Bydgoszcz, Poland
}

\begin{abstract}
The secular changes of height and body mass of girls and boys in the Bydgoszcz region in the period between 1935 and 1991 have been presented in this paper. Over the period of 56 years changes of the traits under investigation showed periodical diversification. Between 1935-1946 a regress was observed, between 1952 and 1971 the greatest average secular changes took place, the years from 1972 to 1979 were characterized by a slowdown in the changes, and in the period from 1979 through 1991 there was a set back in the secular trend of the investigated traits. This is probably due to the fluctuation in the standard of living of the Polish society. The maximum intensification of the secular changes occurs in age groups 13.5 years, 14.5 years, and 15.5 years. Analysis of the research results indicates that the changes are more conspicuous among boys than among girls.
\end{abstract}

KEY WORDS secular changes, physical development, children of Bydgoszcz region Prz. Antropol. - Anthropol. Rev. (2000), vol. 63, pp. 119-125, Tables 2. ISBN 83-8696960-1, ISSN 0033-2003

\section{Introduction}

Physical anthropologists', physicians' and educators' interest in the problems of secular changes in humans, initiated about a 100 years ago, is still very strong. Many researchers believe (see e.g., MALINOWSKI [1977]) that the process of secular changes intensified by the end of the 19th century in the developing countries, and then weakened in the highly developed societies. MILICER [1966] reports that in the period between 1880-1960 the body height of boys (aged between 7 and 14) increased by $15.5 \mathrm{~cm}$ $(11.6 \%)$ and of girls by $13.3 \mathrm{~cm}(10 \%)$, and their body mass grew by $8.8 \mathrm{~kg}$ $(27.4 \%)$ and $9.1 \mathrm{~kg}(28.3 \%)$, respectively.

The research on the tendencies in developmental changes in boys and girls in relation to living conditions, taking into consideration both World Wars and the children's background was carried out by WOLAŃSKI [1977]. PANEK [1970] apart from the height and body mass investigated also the variability of breadth dimensions and studied the process of tooth 
eruption. On the basis of the comparative materials from the period between 1956 and 1966 the author ascertained that the change tendencies were more distinct in rural than in urban areas.

A profound picture of the changes taking place over a long period of time (1880-1972) in children and youth of Poznań was presented by MALINOWSKI [1976]. The results of his study showed that over almost 100 years body height in this population increased on the average by $9.5 \%$, chest circumference by approximately $9 \%$, and head circumference by almost 3\%. A very interesting characterization of the secular changes of body height and body mass in children and youth that took place over a period of 65 years in Łódź was presented by STOLARCZYK \& MALINOWSKI [1996].

Extensive material documenting secular changes of morphological traits among children and youth in Kraków was gathered by BOCHEŃSKA [1978]. She ascertained that in the course of 36 years body height of boys increased on the average by $2.02 \mathrm{~cm}(1.6 \%$ per decade) and in the course of 51 years body height of girls grew by $1.3 \mathrm{~cm}(1 \%)$. In the course of 26 years body mass of boys increased by $0.7 \mathrm{~kg}(4.5 \%)$ in a decade, but the increase in girls was smaller, amounting only to $0.55 \mathrm{~kg}(1.5 \%)$ per decade. Secular changes in the physical development of children and youth in Bydgoszcz were analyzed by NOWICKI [1996].

The authors of the above-mentioned studies concerning secular changes in the physical development of children and youth generally agree that this change trend had a positive character and that it continued roughly till the end of the nineteen seventies.

\section{Materials}

The secular changes taking place in the process of growth and increase of the body mass of children and youth aged from 7.5 to 18.5 years were presented in this paper on the basis of research results representative for the Bydgoszcz region (former provinces of Bydgoszcz, Torun, Włocławek and the present KujawskoPomorskie province). These studies were carried out in:

- 1935 [ĆWIRKO-GODYCKI 1937] on schoolboys from Bydgoszcz primary schools;

- 1946 [TRZEŚNIOWSKI 1963] on 2099 girls and 2049 boys from small towns and villages, and 2004 girls and 1102 boys from big cities;

- 1951 [TRZEŚNIOWSKI 1961] on girls and boys from villages (30.7\%), small towns (38.5\%), and the big cities (30.8\%) of the Bydgoszcz region;

- 1971, 1979 and 1991 [NOWICKI 1996] on children and youth from the big cities (about $1 / 3$ of a total number of individuals), small towns (about 33\%) and villages (about 33\%).

\section{Results and discussion}

Secular changes that occurred between 1935- 1991 in the height and body mass of girls and boys aged 7.5 to 18.5 years are illustrated by the data included in Tables 1 and 2.

Changes of body height of girls in the course of 11 years between the research series from 1935 and 1946 are not unequivocal. Certain age categories (9.5 years, 10.5 years, 14.5 years) show increase while others (11.5 years, 12.5 years, 13.5 years) exhibit regress in the development of the trait. Total values of 
the height of girls investigated in 1946, that is directly after the Second World War, are on average lower by $1.1 \mathrm{~cm}$ per decade than the values obtained for the girls examined in 1935 (Table 1).

A similar phenomenon was observed in that period with regard to the body mass of boys (Table 1), and the regress in the development of this trait was $0.7 \mathrm{~cm}$ per decade on the average. The phenomenon can be explained with a considerable deterioration of the population's social and living conditions during the war and in the early years after its end.

The greatest secular changes of the body height that occurred during the period of the 56 years took place between 1946 and 1951. The data concerning girls examined in 1951 show, that they were taller than the girls of the same age investigated in 1946 (a $3.2 \mathrm{~cm}$ increase per decade). The temporal changes of the body height of boys at that time were even greater and amounted to $5 \mathrm{~cm}$ per decade on the average. An exception to this trend were, however, older girls (16.5 - 18.5 years) and older boys (17.5 - 18.5) whose body height did not reach the stature of their peers investigated in 1946. This can be explained with the fact that the early years of their physical development had fallen in the war period, which might have had negative effect on the growth.

Between 1951 and 1971 (20 years) the trait exhibited further increase of $5.3 \mathrm{~cm}$ on the average in the group of girls $(2.6 \mathrm{~cm}$ per decade) and $5.9 \mathrm{~cm}$ in the group of boys (3 $\mathrm{cm}$ per decade). Different character of the secular changes might be observed between the series from 1971 and 1979. In that period the increase of the body height of boys was very small (only $0.5 \mathrm{~cm}$ on the average, with $0.6 \mathrm{~cm}$ per decade) in comparison to girls who exhibited the average growth of $2 \mathrm{~cm}$ (2.5 per decade).

Between 1979-1991 a further slowdown (arrest) of the secular changes was observed both in girls and in boys $(0.2 \mathrm{~cm}$ per decade). It was probably connected with the economic crisis in Poland and the resultant sudden deterioration of the living conditions of the population.

The secular changes concern also body mass of children and youth in the Bydgoszcz region. The pertinent data are shown in Table 2.

In the first period between the 1935 and 1946 series we have to do with a downward tendency in body mass change. It means that the girls examined in 1946 had average body mass lower by $1.3 \mathrm{~kg}$ (1.1 kg per decade) than the girls examined in 1935, while in boys from those series the decrease was $0.9 \mathrm{~kg}$ $(0.82 \mathrm{~kg}$ per decade). This concerned mainly individuals of both sexes of older ages starting from 11.5 years. The average differences between body mass of the subjects investigated in 1946 and 1951 are the biggest compared to other research series and amount to $1.7 \mathrm{~kg}$ (3.4 per decade) and $2.4 \mathrm{~kg}$ (4.8 kg per decade) for girls and boys, respectively.

Between 1951-1971 body mass of the investigated individuals aged 7.5 to 18.5 years was higher by $4.7 \mathrm{~kg}(2.4 \mathrm{~kg}$ per decade) for girls and $5.8 \mathrm{~kg}(2.9 \mathrm{~kg}$ per decade) for boys. In the next period of time (1971-1979) the secular changes of the body mass of boys were also big and amounted to $2.3 \mathrm{~kg}$ ( $2.9 \mathrm{~kg}$ per decade) but for girls they were slightly smaller at $0.3 \mathrm{~kg}(0.4 \mathrm{~kg}$ per decade). In the final period (1979-1991) the average body mass of boys decreased by $0.4 \mathrm{~kg}$ ( 0.3 per decade), while girls' body mass increased by $0.1 \mathrm{~kg}$ ( $0.08 \mathrm{~kg}$ per decade). 
This suggests that the pace of secular changes in body mass slowed down, similarly to the changes in body height. In the entire period under investigation (1935-1991) the average body height of girls increased by $7.9 \mathrm{~cm}(1.4 \mathrm{~cm}$ per decade $)$ and by $8.4 \mathrm{~cm}(1.5 \mathrm{~cm}$ per decade) for boys.

The value of the secular trend in body mass between 1935-1991 was $5.5 \mathrm{~kg}$ (1.0 $\mathrm{kg}$ per decade) for girls and $9.2 \mathrm{~kg}$ (1.6 per decade) for boys. On the average the biggest secular changes of height and body mass per decade were observed at the age of 13.5-15.5 years for both boys and girls. Similar results were presented by STOLARCZYK \& MALINOWSKI [1996] in reference to children and youth from the Łódź region. In the studies on the reasons of secular changes among a variety of factors, social and economic conditions [TANNER 1963; SALZLER 1968; MILICER 1968; BOCHEŃSKA 1978; BIELICKI \& CHRZANOWSKI 1977; BIELICKI et al. 1981] depending on the level of economic development are often mentioned. Due to its relatively fast pace of economic development after World War II, the Bydgoszcz region was an important element in Poland's economic structure. As a result the living standard of this region's population were improving:

We can distinguish four stages of development in the period from 1945 to 1991:

1. Stage of quantitative growth of consumption (1945-1960)

2. Stage of qualitative coverage of basic needs (1961-1970)

3. Stage of choice - the scope of freedom in the directions of consumption (1971-1974)

4. Stage of regress and a deep economic and social crisis (1975-1989).
The above stages of development of consumption in the population match the secular change direction of the investigated bodily traits. We can observe that the period between 1946-1971, being the period of the greatest secular change in the height and body mass, coincides in time with the first, second and third stages of the population's consumption development. The fourth stage (regress and social and economic crisis) can be associated with the slowdown in temporal changes of height and body mass in both girls and boys.

The phenomenon of the slowdown and regress in the physical development of children and youth in Poland (in the 1980s) is discussed by STOLARCZYK \& MALINOWSKI [1996], GOŁĄB [1994], HULANICKA et al. [1990], and CHARZEWSKI et al. [1991].

\section{References}

Bielicki T., J. Charzewski, 1977, Badania nad przerastaniem rodziców przez potomstwo, Wychowanie Fizyczne i Sport, 3, 49-59

Bielicki T., Z. Welon, A. WaliszKo, 1981, Zmiany w rozwoju fizycznym młodzieży $w$ Polsce w okresie 1955-1978, PWN, Wrocław

BocHEŃSKA Z., 1978, Zmiany $w$ rozwoju osobniczym człowieka w świetle trendów sekularnych i różnic społecznych, WSWF, Kraków

Charzewski J., T. Łaska-MierzejeWSKA, H. PiechaczeK, L. ŁukASZEWSKa, 1991, Wiek menarche dziewczat warszawskich 1976-1986, Wychowanie Fizyczne i Sport, 2, 15-30

ĆWIRKO-GODYCKI M., 1937, Wzrost, waga oraz wskaźnik Pigneta u dzieci szkót powszechnych miasta Bydgoszczy, Przegląd Antropologiczny, XI, $1-9$

GoląB S., 1994, Stan badań ontogenetycznych dziecka polskiego prowadzonych $w$ Katedrze Antropologii i Anatomii AWF w Krakowie, [in:] Ontogeneza dziecka polskiego, Monografia 315, AWF, Poznań 
Hulanicka B., C. Brajczewski, W. JedlińSKA, T. SŁawińsKa, A. Waliszko, 1990, Duże miasto - małe miasto - wieś, Zakład Antropologii PAN, Wrocław

MALINOWSKI A., 1976, Zmiany sekularne $w$ rozwoju fizycznym dzieci $i$ młodzieży miasta Poznania, [in:] Antropologia Polska. Aktualny stan badań, Monografia 80, AWF, Poznań

MALINOWSKI A., 1977, Trend sekularny $i$ akceleracja - przegląd zagadnień, Przegląd Antropologiczny, 43, 406

MiLICER H., 1966, Zjawisko trendu sekularnego $w$ populacji polskiej, Wychowanie Fizyczne i Sport, $\mathbf{X}, 4-18$

MiLICER H., 1968, O zjawisku zwiększania sie wymiarów ciała współczesnego człowieka, Przegląd Zoologiczny, 12, 190

NowICKI G., 1996, Zmiany międzypokoleniowe rozwoju somatycznego i sprawności fizycznej dzieci i młodzieży szkolnej. Region bydgoski 1935-1991, WSP, Bydgoszcz
PANEK S., 1970, The secular trend in the growth of polish urban and rural children examined in 1956 and 1966, Materiały i Prace Antropologiczne, 79, 3-29

SAlzler A., 1968, Pričiny i formy projavlenija uskorennogo rosta detej, Medicina, Moskva

Stolarczyk H., A. Malinowski, 1996, Secular changes of body height and mass in the children and addescents of Łódź, Z. Morph. Anthrop., 81, 167-177

TANNER J.M., 1963, Rozwój w okresie pokwitania, PZWL, Warszawa

TRZEŚNIOWSKI R., 1961, Rozwój fizyczny i sprawność fizyczna młodzieży polskiej, Nasza Księgarnia, Warszawa

TRZEŚNIOWSKI R., 1963, Rozwój fizyczny młodzie$\dot{z} y$ pomorskiej $w$ świetle badań z $1946 r$., Roczniki Naukowe AWF, Warszawa, II, $165-195$

WOLAŃSKi N., 1977, Rozwój biologiczny człowie$k a$, PWN, Warszawa

\section{Streszczenie}

W pracy przedstawiono zmiany sekularne wysokości i masy ciała u dziewcząt i chłopców regionu bydgoskiego w okresie od 1935 do 1991 roku. W czasie 56 lat zmiany w rozwoju badanych cech wykazuja okresowe zróżnicowanie. W latach 1935-1946 ma miejsce regres, w latach 1952-1971 zmiany sekularne są przeciętnie największe, lata 1972-1979 charakteryzują się ich spowolnieniem, a w ostatnim okresie 1979-1991 widoczne jest zahamowanie trendu sekularnego badanych cech. Można przypuszczać, że ma to związek z wahaniami poziomu życia społeczeństwa polskiego. Maksymalne natężenie zmian międzypokoleniowych występuje w wieku od 13,5 do 15,5 lat. Analiza wyników badań wskazuje, że zaznaczają się one bardziej u chłopców niż u dziewcząt. 
Table 1. Secular changes of the body height of girls and boys from the Bydgoszcz region $(\mathrm{cm})$

\begin{tabular}{|c|c|c|c|c|c|c|c|c|c|c|c|c|c|c|c|c|c|c|}
\hline \multirow[t]{3}{*}{ Age } & \multicolumn{18}{|c|}{ Year of the investigation / Author } \\
\hline & \multicolumn{3}{|c|}{$\begin{array}{c}1935 \\
\text { Ćwirko-Godycki }\end{array}$} & \multicolumn{3}{|c|}{$\begin{array}{c}1946 \\
\text { Trześniowski }\end{array}$} & \multicolumn{3}{|c|}{$\begin{array}{c}1951 \\
\text { Trześniowski }\end{array}$} & \multicolumn{3}{|c|}{$\begin{array}{c}1971 \\
\text { Nowicki } \\
\end{array}$} & \multicolumn{3}{|c|}{$\begin{array}{c}1979 \\
\text { Nowicki }\end{array}$} & \multicolumn{3}{|c|}{$\begin{array}{c}1991 \\
\text { Nowicki }\end{array}$} \\
\hline & $N$ & $X$ & $S D$ & $N$ & $x$ & $S D$ & $N$ & $X$ & $S D$ & $N$ & $x$ & $S D$ & $N$ & $X$ & $S D$ & $N$ & $X$ & $S D$ \\
\hline \multicolumn{19}{|c|}{ GIRLS } \\
\hline 7.5 & 114 & 116.0 & 4.92 & - & - & - & - & - & - & 1835 & 123.4 & 5.69 & 100 & 125.4 & 7.56 & 364 & 125.6 & 6.82 \\
\hline 8.5 & 131 & 121.5 & 5.27 & - & - & - & - & - & - & 1783 & 128.8 & 5.79 & 100 & 130.3 & 7.27 & 359 & 130.7 & 6.99 \\
\hline 9.5 & 129 & 126.7 & 5.54 & 463 & 128.4 & 6.72 & - & - & - & 1813 & 133.7 & 6.13 & 100 & 135.2 & 7.36 & 372 & 135.5 & 7.21 \\
\hline 10.5 & 145 & 131.2 & 6.38 & 465 & 131.5 & 6.79 & 123 & 135.8 & 6.28 & 1875 & 139.4 & 6.92 & 100 & 140.8 & 7.83 & 426 & 140.7 & 7.56 \\
\hline 11.5 & 147 & 138.8 & 6.93 & 533 & 135.6 & 7.67 & 130 & 138.5 & 6.63 & 2277 & 145.4 & 7.23 & 100 & 147.1 & 7.82 & 417 & 147.3 & 7.49 \\
\hline 12.5 & 118 & 145.8 & 6.79 & 519 & 140.4 & 7.14 & 129 & 143.2 & 7.12 & 2236 & 151.5 & 7.12 & 100 & 152.7 & 7.74 & 421 & 152.8 & 7.84 \\
\hline 13.5 & 136 & 148.5 & 6.67 & 440 & 146.2 & 6.45 & 131 & 151.2 & 7.18 & 2285 & 155.8 & 6.33 & 100 & 156.9 & 7.35 & 446 & 157.0 & 7.80 \\
\hline 14.5 & 132 & 149.6 & 6.85 & 397 & 151.1 & 5.91 & 117 & 152.4 & 7.04 & 2206 & 159.0 & 5.77 & 100 & 161.3 & 7.24 & 416 & 161.4 & 7.15 \\
\hline 15.5 & - & - & - & 301 & 154.7 & 4.93 & 116 & 155.5 & 6.63 & 1629 & 160.7 & 5.52 & 100 & 163.1 & 7.39 & 420 & 163.4 & 6.98 \\
\hline 16.5 & - & - & - & 546 & 157.1 & 4.76 & 120 & 156.9 & 5.8 & 1358 & 161.3 & 5.15 & 100 & 163.9 & 7. & 384 & 164.3 & 7.14 \\
\hline 17.5 & - & - & - & 154 & 159.2 & 5.69 & 119 & 157.0 & 5.6 & 1034 & 161.7 & 5.32 & 100 & 164.7 & 7.18 & 365 & 165.1 & 6.99 \\
\hline 18.5 & - & - & - & 285 & 158.9 & 5.31 & 108 & 158.8 & 5.49 & 617 & 161.9 & 5.31 & 100 & 165.0 & 7.24 & 341 & 165.2 & 7.04 \\
\hline \multicolumn{19}{|c|}{ BOYS } \\
\hline 7.5 & 112 & 116.7 & 5.06 & - & - & - & - & - & - & 1867 & 124.5 & 5.68 & 100 & 124.9 & 4.34 & 356 & 125.1 & 5.42 \\
\hline 8.5 & 136 & 122.4 & 5.74 & - & - & - & - & - & - & 1789 & 130.2 & 5.87 & 100 & 131.0 & 5.13 & 369 & 131.3 & 5.20 \\
\hline 9.5 & 129 & 127.6 & 6.09 & 212 & 128.9 & 6.19 & - & - & - & 1814 & 134.9 & 6.28 & 100 & 135.6 & 5.09 & 354 & 136.0 & 5.12 \\
\hline 10.5 & 149 & 131.5 & 5.28 & 443 & 131.9 & 6.08 & 129 & 132.7 & 6.09 & 1905 & 139.8 & 6.43 & 100 & 140.8 & 5.10 & 406 & 141.1 & 5.26 \\
\hline 11.5 & 138 & 136.4 & 6.59 & 514 & 135.3 & 6.75 & 126 & 139.8 & 6.54 & 2050 & 144.8 & 6.76 & 100 & 145.3 & 5.19 & 428 & 145.6 & 5.40 \\
\hline 12.5 & 151 & 142.6 & 6.94 & 490 & 139.7 & 7.36 & 130 & 143.7 & 6.72 & 2124 & 149.9 & 7.67 & 100 & 149.9 & 5.81 & 415 & 150.0 & 6.04 \\
\hline 13.5 & 132 & 147.0 & 7.99 & 453 & 144.9 & 8.35 & 121 & 148.4 & 8.01 & 2063 & 156.6 & 8.16 & 100 & 156.8 & 5.90 & 405 & 156.9 & 6.12 \\
\hline 14.5 & 121 & 150.0 & 8.35 & 461 & 149.8 & 8.92 & 148 & 154.7 & 8.53 & 2057 & 163.9 & 8.26 & 100 & 163.9 & 6.63 & 431 & 163.8 & 7.15 \\
\hline 15.5 & - & - & - & 256 & 156.8 & 8.43 & 126 & 160.9 & 7.98 & 1748 & 168.9 & 7.21 & 100 & 169.0 & 6.54 & 399 & 169.2 & 7.02 \\
\hline 16.5 & - & - & - & 152 & 163.0 & 7.25 & 130 & 166.6 & 7.47 & 1483 & 171.7 & 6.61 & 100 & 172.0 & 6.67 & 391 & 172.8 & 6.90 \\
\hline 17.5 & - & - & - & 100 & 168.8 & 5.76 & 131 & 167.2 & 6.51 & 1253 & 173.6 & 6.27 & 100 & 175.9 & 6.47 & 373 & 175.8 & 6.78 \\
\hline 18.5 & - & - & - & 70 & 169.6 & 6.31 & 132 & 168.6 & 5.87 & 341 & 176.1 & 5.63 & 100 & 176.3 & 6.44 & 350 & 176.5 & 6.61 \\
\hline
\end{tabular}


Table 2. Secular changes of the body mass of girls and boys from the Bydgoszcz region (kg)

\begin{tabular}{|c|c|c|c|c|c|c|c|c|c|c|c|c|c|c|c|c|c|c|}
\hline Age & \multicolumn{18}{|c|}{ Year of the investigation / Author } \\
\hline & \multicolumn{3}{|c|}{$\begin{array}{c}1935 \\
\text { Ćwirko-Godycki }\end{array}$} & \multicolumn{3}{|c|}{$\begin{array}{c}1946 \\
\text { Trześniowski }\end{array}$} & \multicolumn{3}{|c|}{$\begin{array}{c}1951 \\
\text { Trześniowski }\end{array}$} & \multicolumn{3}{|c|}{$\begin{array}{c}1971 \\
\text { Nowicki }\end{array}$} & \multicolumn{3}{|c|}{$\begin{array}{c}1979 \\
\text { Nowicki }\end{array}$} & \multicolumn{3}{|c|}{$\begin{array}{c}1991 \\
\text { Nowicki }\end{array}$} \\
\hline & $N$ & $x$ & $S D$ & $N$ & $x$ & $S D$ & $N$ & $x$ & $S D$ & $N$ & $X$ & $S D$ & $N$ & $x$ & $S D$ & $N$ & $x$ & $S D$ \\
\hline \multicolumn{19}{|c|}{ GIRLS } \\
\hline 7.5 & 114 & 20.5 & 2.85 & - & - & - & - & - & - & 1835 & 24.3 & 3.83 & 100 & 25.0 & 5.94 & 364 & 25.2 & 4.90 \\
\hline 8.5 & 131 & 22.8 & 2.93 & - & - & - & - & - & - & 1783 & 27.1 & 4.61 & 100 & 27.5 & 5.54 & 359 & 26.9 & 5.08 \\
\hline 9.5 & 129 & 25.4 & 3.33 & 463 & 26.1 & 3.92 & - & - & - & 1813 & 29.8 & 5.02 & 100 & 30.3 & 5.83 & 372 & 30.6 & 5.92 \\
\hline 10.5 & 145 & 27.5 & 3.75 & 465 & 27.9 & 3.63 & 123 & 27.9 & 4.84 & 1875 & 33.0 & 5.78 & 100 & 33.5 & 4.96 & 426 & 33.5 & 5.90 \\
\hline 11.5 & 147 & 32.3 & 4.95 & 533 & 29.9 & 4.37 & 130 & 32.5 & 5.51 & 2277 & 37.1 & 6.57 & 100 & 37.3 & 5.04 & 417 & 37.5 & 6.12 \\
\hline 12.5 & 118 & 37.4 & 6.30 & 519 & 33.2 & 5.78 & 129 & 35.6 & 6.08 & 2236 & 42.2 & 7.48 & 100 & 42.4 & 5.28 & 421 & 42.5 & 6.21 \\
\hline 13.5 & 136 & 40.2 & 6.35 & 440 & 37.5 & 7.08 & 131 & 40.9 & 6.73 & 2285 & 46.7 & 7.48 & 100 & 47.4 & 5.16 & 446 & 47.6 & 5.84 \\
\hline 14.5 & 132 & 40.9 & 6.20 & 397 & 41.5 & 7.15 & 117 & 43.9 & 6.99 & 2206 & 50.7 & 7.08 & 100 & 50.9 & 5.23 & 416 & 50.8 & 5.70 \\
\hline 15.5 & - & - & - & 301 & 46.1 & 7.59 & 116 & 49.0 & 6.61 & 1629 & 53.2 & 6.27 & 100 & 53.4 & 5.16 & 420 & 53.2 & 6.03 \\
\hline 16.5 & - & - & - & 546 & 49.3 & 6.24 & 120 & 50.4 & 6.21 & 1358 & 54.4 & 6.14 & 100 & 54.7 & 5.18 & 384 & 54.8 & 5.87 \\
\hline 17.5 & - & - & - & 154 & 52.7 & 5.96 & 119 & 53.0 & 6.04 & 1034 & 55.5 & 6.11 & 100 & 55.9 & 5.18 & 365 & 56.3 & 5.32 \\
\hline 18.5 & - & - & - & 285 & 52.8 & 5.76 & 108 & 53.0 & 6.26 & 617 & 56.0 & 6.01 & 100 & 56.3 & 5.15 & 341 & 56.6 & 5.64 \\
\hline \multicolumn{19}{|c|}{ BOYS } \\
\hline 7.5 & 112 & 21.1 & 2.32 & - & - & - & - & - & - & 1867 & 25.2 & 3.79 & 100 & 27.0 & 6.33 & 356 & 26.9 & 5.52 \\
\hline 8.5 & 136 & 23.9 & 2.71 & - & - & - & - & - & - & 1789 & 28.0 & 4.20 & 100 & 31.2 & 6.50 & 369 & 30.9 & 5.91 \\
\hline 9.5 & 129 & 26.4 & 3.12 & 212 & 27.6 & 3.43 & - & - & - & 1814 & 30.6 & 4.60 & 100 & 33.2 & 6.53 & 354 & 33.3 & 6.14 \\
\hline 10.5 & 149 & 28.6 & 3.41 & 443 & 28.7 & 3.61 & 129 & 29.9 & 4.41 & 1905 & 33.7 & 5.16 & 100 & 35.4 & 5.47 & 406 & 34.9 & 5.84 \\
\hline 11.5 & 138 & 31.8 & 3.31 & 514 & 30.7 & 4.19 & 126 & 32.8 & 4.99 & 2050 & 37.0 & 6.19 & 100 & 43.9 & 4.42 & 428 & 42.8 & 5.12 \\
\hline 12.5 & 151 & 35.2 & 5.02 & 490 & 32.9 & 5.65 & 130 & 34.9 & 5.51 & 2124 & 40.5 & 7.15 & 100 & 45.3 & 4.51 & 415 & 44.9 & 5.36 \\
\hline 13.5 & 132 & 38.5 & 5.89 & 453 & 36.5 & 6.58 & 121 & 39.2 & 6.40 & 2063 & 45.9 & 7.83 & 100 & 47.7 & 4.73 & 405 & 47.2 & 5.47 \\
\hline 14.5 & 121 & 40.9 & 6.29 & 461 & 40.4 & 7.50 & 148 & 44.8 & 7.56 & 2057 & 52.7 & 8.29 & 100 & 55.2 & 4.83 & 431 & 54.0 & 5.24 \\
\hline 15.5 & - & - & - & 256 & 46.1 & 7.80 & 126 & 50.6 & 7.92 & 1748 & 57.9 & 8.04 & 100 & 58.9 & 5.57 & 399 & 58.0 & 5.15 \\
\hline 16.5 & - & - & - & 152 & 52.1 & 6.85 & 130 & 54.8 & 7.48 & 1483 & 61.3 & 7.41 & 100 & 62.6 & 5.55 & 391 & 62.1 & 5.62 \\
\hline 17.5 & - & - & - & 100 & 57.1 & 6.41 & 131 & 57.4 & 6.99 & 1253 & 64.2 & 6.87 & 100 & 65.4 & 5.25 & 373 & 65.5 & 5.38 \\
\hline 18.5 & - & - & - & 70 & 60.7 & 6.36 & 132 & 62.8 & 6.60 & 341 & 66.1 & 6.65 & 100 & 66.6 & 5.28 & 350 & 66.7 & 5.51 \\
\hline
\end{tabular}

